\title{
The Effect of RAFT Strategy on Students' Writing Ability
}

\author{
Prihatin Nurhidayati \\ Institut Agama Islam Negeri Bengkulu \\ athinbengkulu01@gmail.com \\ Heny Friantary \\ Institut Agama Islam Negeri Bengkulu \\ henyfriantary30@gmail.com \\ Hengki Satrisno \\ Institut Agama Islam Negeri Bengkulu \\ hengkidalima@gmail.com \\ Feny Martina \\ Institut Agama Islam Negeri Bengkulu \\ feny@iainbengkulu.ac.id
}

\begin{abstract}
Language skills must be owned by students. Therefore, the teacher's role is very important in the learning process because it must be able to provide strategic, innovative, and interesting methods, strategies, and learning media so that students are able to master the four language skills in Indonesian lessons, meaning that students must master these four skills in a balanced way. However, in reality, writing skills are still less favored by students, this is due to the number of students who have difficulty expressing ideas, feelings, and thoughts through writing. So that learning to write is more difficult than the three competencies in other language learning. The purpose of this study was to determine the effect of the RAFT strategy on the development of descriptive text writing skills for students of class X IPA1 SMA Negeri 2 Seluma. The type of research used is quantitative research. The sample of this study was 34 people. The instruments used are test sheets and documentation. The results obtained from this study, it is known that the hypothesis test was carried out, it was obtained that the value of $F_{\text {count }}>F_{\text {table }}$ i.e. $=0.48>0.39$, thus the hypothesis Ha was accepted, which means that the implementation of the RAFT strategy can improve the development of text writing skills. description of students of class X IPA1 SMA Negeri 2 Seluma. The implementation of the influence test in the results of this study found that the raft learning strategy on the development of writing skills in class X IPA1 SMA Negeri 2 Seluma, with the results of data management from the research conducted, it is known that there is a positive influence between RAFT strategy (X) on the development of descriptive text writing skills (Y).
\end{abstract}

Keywords: RAFT Strategy, Writing Skill, descriptive text

\section{A. Introduction}


Writing skills are very important and are the main elements in seeing a person's ability to speak. The ability of students to learn to write will always have a positive impact on the students themselves, both in the ability to express their ideas and for their provision in the world of further education and even the world of work. Thus, it is hoped that through essay writing activities, students will be skilled in writing which in turn can improve their language skills. Teaching writing to students is not an easy thing because in writing activities it cannot be done once, it need s in-depth coaching. The time provided for Indonesian language subjects is lacking, which has an impact on fostering students' writing skills, so it is very necessary to have the right method to be able to teach writing to students so that students think writing is fun (Septi: 2016).

In teaching and learning activities, especially descriptive text material, the teacher guides students in expressing their ideas, ideas, and opinions on an ongoing basis which are outlined in written form. Learning to write must be studied seriously and requires special training, and there are still many students who think that writing skills are a scary lesson to learn. This causes many students who lack or even have no interest in learning languages, especially writing descriptive text skills.

The writing exercise begins by explaining the theories about how to write, then asking students to choose a topic and then make an outline, based on the outline of the essay students are asked to develop it into an essay. And so on, and applies at various levels and types of education. Writing exercises in the form of making essays are always the final activity of a long theoretical explanation and that results in essay writing exercises being rarely carried out.

Based on the results of pre-research observations conducted by researchers at SMA Negeri 2 Seluma, the learning process carried out at SMA Negeri 2 Seluma is still conventional. Learning is still teacher-centered, and students 
are only subjects in learning, and in the end, students are less active in teaching and learning activities.

Based on the results of the implementation of the learning carried out, it is known that the average student achievement is low. These results indicate that class $\mathrm{X}$ students are not used to and are less trained in writing. From the results of interviews with teachers in the field of study, it is known that the writing difficulties experienced by class X SMA Negeri 2 Seluma students in writing descriptive texts (Melda: 2020).

Based on the problems above, the authors need to improve, namely by implementing learning strategies that can create a pleasant atmosphere for students, thus causing an active learning process. The low result of writing student description texts is expected to be improved by the teacher by applying the RAFT strategy which can make it easier for students to come up with and put ideas into writing. After that, students pour the ideas that have been obtained into descriptive text.

\section{B. Research Methods}

This research uses a quasi-experimental type of research (quasiexperimental) which is a research that approaches Experimental research where it is not possible to have full control over the relevant variables. The design used in this study is the Non-Equivalent Control Group Design. Because in this design there is an experimental group that is given treatment and the control group is not given treatment. Both classes were given the same material to determine student learning outcomes obtained from both pretest and posttest tests. (Sugiyono: 2007) The population in this study were all students of class X IPA 1 SMA Negeri 2 Seluma totaling 34 students and class $\mathrm{X} \mathrm{IPA}_{2}$ totaling 34 students. The sample to be studied will have two classes, namely class X IPA 1 which becomes the experimental class and will be given treatment or action on the RAFT strategy learning model, and class IPA $_{2}$ which becomes the control class. 
Data collection techniques used in this research are tests, and documentation (Sugiyono: 2007), data analysis techniques carried out by statistical analysis prerequisite test starting from the data normality test, homogeneity test, and linearity test (Sugiyono: 2007).

\section{Results and Discussion}

\section{Results}

\section{Analysis of Differences in Values for Experimental Class and Control Class}

The learning outcomes data in this study were pretest and posttest learning outcomes data. The pretest is a test conducted to know the initial ability of students before being given treatment. While the posttest aims to determine the differences in student learning outcomes after being given treatment/treatment.

Before being given treatment, students were given a pretest to determine the initial ability of students as much as 1 question. Afterknowing the initial abilities of students, then students are taught using the RAFT strategy. At the last meeting, students were given a post-test to find out student learning outcomes as much as 1 piece of the same question with an assessment using a scale of 100.

The pretest value of the experimental group that had not been treated or pretest was determined as the initial value with an average of 67.38 and after the RAFT strategy was carried out the average posttest was 78.61 .

\section{Analysis of the Effect of Strategy RAFT on Improving Writing Skills in Class X Science 1 SMA Negeri 2 Seluma}

The analysis test in this study was carried out using the SPSS 1.6 program from the implementation of the test known as follows:

\section{Model Summary}




\begin{tabular}{|l|r|r|r|r|}
\hline Model & \multicolumn{1}{|c|}{$\mathrm{R}$} & $\mathrm{R}$ Square & $\begin{array}{c}\text { Adjusted } \mathrm{R} \\
\text { Square }\end{array}$ & $\begin{array}{c}\text { Std. The error of the } \\
\text { Estimate }\end{array}$ \\
\hline 1 & $.236^{\mathrm{a}}$ & .056 & .026 & 7.33545 \\
\hline
\end{tabular}

a. Predictors: (Constant), pretest value

From the table above, it is known that the adjusted R Square value is $0.026<\mathrm{R}$ square value 0.056 . Thus, it is known that there is an influence between the RAFT strategy on improving the skills of writing descriptive texts for students of class X IPA SMA Negeri 2 Seluma.

\section{Results of Research Hypothesis t-}

Test This t-test was conducted to answer the hypothesis in this study using the SPSS 1.6 program, from the results of data processing, it is known as follows:

\section{Coefficients*}

\begin{tabular}{|l|c|c|c|c|c|}
\hline \multirow{2}{*}{ Model } & \multicolumn{2}{|c|}{$\begin{array}{c}\text { Unstandardized } \\
\text { Coefficients }\end{array}$} & $\begin{array}{c}\text { Standardized } \\
\text { Coefficients }\end{array}$ & & \\
\cline { 2 - 4 } & $\mathrm{B}$ & Std. Error & Beta & $\mathrm{t}$ & Sig. \\
\hline 44,335 & & (Constant) & & 3,069 & .004 \\
14,448 & & .193 & & 1,374 & .266 \\
Nilaipretes & .236 .179 & & & & \\
\hline
\end{tabular}

a. Dependent Variable: posttest

value

The results of the significance test by applying the t-test obtained $\mathrm{t} \_$count $=1.374$, it turns out to be far outside the area of acceptance of the null hypothesis (Ho), where t_table at the test level of $1 \%(0.01)$ with dk $=34$ is obtained at 0.496 . This means that the $t$-count value is much greater 
than the t-table value, the test criteria for the $t$-statistical test are accepted $\mathrm{H} 0$ if $-\mathrm{t} 1 / 2<\mathrm{t}<\mathrm{t} 1-\mathrm{t} 1 / 2$. In this case, it can be said to reject Ho and accept Ha, which means that there is an effect of using the RAFT Strategy on student learning outcomes at SMA Negeri 2 Seluma, especially in Indonesian subjects.

\section{Discussion}

According to Carol Santa (Septi: 2016), the RAFT strategy is a strategy that can free students from choosing topics. In addition, students are formed in groups so that students can exchange ideas with other group members regarding the topics to be discussed. This strategy is suitable in learning to write texts because students are formed in groups so that students can have discussions with their groups. Thus, it is hoped that students will find it easier to express the ideas that will be outlined in the descriptive text.

After testing the hypothesis of student learning outcomes as a whole, it can be concluded that Ho is rejected, while Ha is accepted. Ha stated that the average learning outcomes of students who studied using the RAFT strategy were higher than those of students who studied conventionally. it can be seen that there is a significant difference between the posttest average value, which is 78.61, which is higher than the posttest average value, which is 67.38. After analyzing the research results, several things cause the difference in the average value of these causes.

The RAFT (Role-Audience-Format-Topic) strategy is expected to be a strategy that can facilitate students in learning to write descriptive texts. In the RAFT Strategy (Role-Audience-Format-Topic), students can choose their writing topic and can exchange ideas with their group mates about the topic that will be developed into a descriptive text. Thus, it is hoped that students will not run out of ideas when writing descriptive texts. However, 
if all groups do not understand the topic to be discussed, students will have difficulty brainstorming before writing a descriptive text.

Shearer Ruddel(2015) found that after using RAFT on many students at various grade levels, students liked RAFT. However, the problem of a range of choices often arises, namely: starting from a few choices and then developing into many choices.

Students in the experimental class feel comfortable learning because the learning process carried out is different from the learning process they usually do. The difference in student learning outcomes between experimental and control class students is because at each stage of learning the RAFT strategy is a cooperative learning model designed to increase students' sense of responsibility for their learning and the learning of others. Students not only learn the material given, but they also have to be ready to give and teach the material to their colleagues.

While conventional only emphasizes the teacher who is more active in the learning process. Teachers are also more creative in the learning process. After processing the research data, in general, the research shows that learning Indonesian with the RAFT strategy can have a positive influence on improving students' Indonesian learning outcomes. This increase in student learning outcomes can be seen from the way students answer post-test questions by the experimental class students with an average test score of 75.71, which is better than the control class students with an average score of 67.02 .

\section{Conclusion}

From the results of the research and discussion in this study, it can be concluded that: 
1. The results of the hypothesis test carried out, it was found that the value of $F_{\text {count }}>F_{\text {table }}$ i.e. $=1.374>0.496$ thus the hypothesis Ha was accepted, which means that the implementation of the RAFT strategy can improve skills development write a descriptive text for students of class X IPA1 SMA Negeri 2 Seluma.

2. The implementation of the influence test in the results of this study is known that the raft learning strategy on the development of writing skills in class $X$ IPA1 SMA Negeri 2 Seluma, with the results of data management from the research conducted, it is known that there is a positive influence between the RAFT (X) strategy on the development of text writing skills description (Y). 


\section{REFERENCES}

Akhaidah, S, et al. (2004). Development of Indonesian Writing Ability. Jakarta: Erlangga.

Alwasilah, C., and Alwasilah, S.Z. (2005). Just Writing (A New Way of Writing with the Collaborative Method). Bandung: The Ultimate Book Qibla.

Agni. (2014). Writing Skills). (2014). Taken from: http://ayusgirikiqrimananikimi.blogspot.co.id/2014/II/Keterampilan Menulis.html?M=1, Downloaded on January 6, 2018, at 20:44.

Darmadi, K. (2010). Improving Writing Ability. Yogyakarta: Andi.

Ministry of Education and Culture. 2008. Big Indonesian Dictionary. Jakarta: Language Center.

Ministry of Education and Culture. (2011). Improved General Guidelines for Indonesian Spelling \& General Guidelines for the Formation of Terms. Jakarta: Victory Inti Cipta.

Enre, F.A. (2012). Fundamentals of Writing Skills. Jakarta: Ministry of Education and Culture.

Eva, S.B. (2012). Improving Writing Ability in Indonesian Language Learning Through Non-Example Example Models in Class V of Medan State Elementary School: Indonesian Language Journal. Vol. 7, No. 1:9.

FKIP Unismuh Makassar. (2017). Guidelines for Thesis Writing. Revised Edition 1. Makassar: Panrita Press Unismuh Makassar.

Gie, T.L. (2002). Skilled Writing. Yogyakarta: Andi.

Hanisyah, R.A. (2011). Application of Mind Maps as an Effort to Improve Writing Essay Skills for Class X Students of Vocational High School (SMK) PGRI Babakanmadang. Essay. http://respository.uinjkt.ac.id/. Downloaded on January 1, 2018.

Iskandar, W., \& Dadang, S. (2008). Language Learning Strategy. Bandung: Rosdakarya Youth.

Keraf, G. (2014). Exposition and Description. Flores: Nusa Indah.

Ruddel, M. (2015). Teaching Content. USA: Reading and Writing.

Sugiyono. (2016). Educational Research Methods Quantitative, Qualitative and $R \& D$ Approaches. Bandung: Alphabeta.

Interview with Mrs. Melda, S.Pd (Teacher of Indonesian Language Studies), 28 September 2020

Wuryani. S. (2016). The Effectiveness of Role-Audience-Format-Topic (RAFT) Learning Strategy in News Writing Learning for Class VIII Students of SMP Negeri 3 Pajangan Bantul. Essay. Yogyakarta: Yogyakarta State University. 